\title{
Hubungan antara Levels of Inquiry (LoI) dan Keterampilan Proses Sains dalam Pembelajaran IPA
}

\author{
Syafrilianto \\ Pendidikan Guru Madrasah Ibtidaiyah, FTIK, Institut Agama Islam Negeri Padangsidimpuan \\ syafrilianto@iain-padangsidimpuan.ac.id
}

\begin{abstract}
Abstrak
Proses pembelajaran IPA diidentikkan seperti cara para ilmuwan memperoleh teori atau konsep yang dikenal dengan metode ilmiah. Salah satu pendekatan pembelajaran yang sesuai dengan pembelajaran IPA adalah Levels of Inquiry. Artikel ini merupakan studi analisis literatur yang mendeskripsikan tentang karakteristik Levels of inquiry dalam pembelajaran IPA serta hubungannya dengan keterampilan proses sains. Berdasarkan analisis literatur yang dilakukan, diperoleh hubungan antara pendekatan levels of inquiry dan keterampilan proses sains dalam pembelajaran IPA. Hal ini disebabkan karena pada tiap tahapan levels of inquiry melatihkan keterampilan proses sains yang berbeda sesuai dengan level atau tingkatannya, mulai dari level terendah yaitu discovery learning yang melatihkan rudimentary skills hingga level tertinggi hypothetical inquiry yang melatihkan advanced skills. Dengan demikian, Levels of Inquiry memiliki hubungan dengan keterampilan proses sains sehingga dapat dijadikan sebagai salah satu alternatif pendekatan pembelajaran IPA untuk melatihkan dan meningkatkan keterampilan proses sains mulai jenjang pendidikan dasar,menengah hingga jenjang pendidikan tinggi.
\end{abstract}

Kata Kunci: Levels of inquiry, Keterampilan proses sains, Pembelajaran IPA

\section{Latar Belakang}

Pembelajaran IPA di sekolah diharapkan dapat menjadi wahana bagi peserta didik untuk mempelajari diri sendiri dan alam sekitarnya serta mampu menerapkan pengetahuan tersebut dalam kehidupan sehari-hari. Pembelajaran IPA juga menekankan pada pengalaman langsung untuk mengembangkan kemampuan peserta didik sehingga memiliki kompetensi dalam memahami alam sekitar melalui proses mencari tahu dan melakukan, sehingga dapat membantu mereka untuk memperoleh keterampilan dan pemahaman yang lebih mendalam terhadap IPA. Oleh karena itu, melalui kegiatan dan pengalaman belajar IPA hendaknya siswa memiliki berbagai macam keterampilan termasuk keterampilan kognitif (intelektual), manual (psikomotor) dan sosial (sikap). Keterampilan-keterampilan tersebut merupakan keterampilan-keterampilan yang terlibat dalam keterampilan proses sains (Rustaman, 2005). 
Penerapan Levels of Inquiry (LoI) dalam pembelajaran IPA akan lebih dapat menciptakan suasana belajar dan proses pembelajaran dalam rangka memfasilitasi siswa dalam melatihkan dan mengembangkan keterampilan proses sains serta meningkatkan hasil belajar kognitif siswa. Hal ini sejalan dengan pendapat Wenning yang menyatakan bahwa ketika pembelajaran dilakukan dengan menggunakan pendekatan Levels of Inquiry(LoI), siswa memiliki kesempatan untuk melakukan observasi, merumuskan hipotesis, mengumpulkan dan menganalisis data, mengembangkan prinsipprinsip ilmiah, mensintesis hukum, dan membuat serta mengujikan hipotesis untuk menghasilkan penjelasan (Wenning, 2011). Di samping itu, melalui Levels of Inquiry siswa akan memperoleh pengalaman belajar dan dapat meningkatkan keterampilan proses sains serta kemampuan kognitif mereka secara bertahap karena dalam pembelajaran, pendekatan levels of Inquiry (LoI) dilaksanakan secara sistematis dan hirearki untuk meningkatkan dan mengembangkan keterampilan-keterampilan proses intelektual dan ilmiah dengan menonjolkan inkuiri secara sistematis dan komprehensif (Wenning, 2011).

Disisi lain, keterampilan proses sains merupakan salah satu kompetensi yang sangat penting dilatihkan dan dikuasai oleh siswa. Hal ini disebabkan karena keterampilan proses sains sebagai bekal untuk menggunakan metode ilmiah dalam mengembangkan sains serta diharapkan memperoleh pengetahuan baru/ mengembangkan pengetahuan yang telah dimiliki. Keterampilan proses sains dapat mempengaruhi perkembangan pengetahuan siswa. Membiasakan siswa belajar melalui proses kerja ilmiah, selain dapat melatih detail keterampilan ilmiah dan kerja sistematis, dapat pula membentuk pola berpikir siswa secara ilmiah.

\section{Hasil dan Pembahasan}

Levels of Inquiry dalam pembelajaran sains menurut Wenning (2005, 2010 dan 2011) dipandang sebagai suatu pendekatan sistematis dalam pembelajaran untuk meningkatkan pengembangan keterampilan-keterampilan proses intelektual dan ilmiah melalui inkuiri yang dilakukan secara sistematis dan komprehensif. Dengan demikian ketika seorang pendidik maupun peneliti ingin menerapakan pembelajaran inkuiri hendaknya memahami bahwa levels of inquiry diterapkan secara sistematis dan komprehensif, bukan secara parsial dan terpisah antara satu tahapan dengan tahapan yang lain. Hal ini disebabkan karena ketika para pendidik memahami dan menerapkan levels of inquiry dalam pembelajaran secara acak tidak akan membantu mereka dalam menuntun siswa-siswanya melakukan saintifik inkuiri (Wenning, 2005). 
Namun dalam parktek-praktek pembelajaran sains, kebanyakan pendidik ataupun peneliti di bidang pendidikan sains melakukan pembelajaran inkuiri secara parsial dan terpisah tanpa menerapkan levels of inquiry secara sistematis dan komprehensif. Hal ini akan mengakibatkan kebingungan bagi siswa ketika diberikan pembelajaran inkuiri secara langsung tanpa melalui tahaptahap inkuiri tersebut. Wenning(2005) menyatakan bahwa:

For instance, the author's recent experience with a secondary-level student teacher resulted in the revelation of a significant pedagogical problem. The student teacher was supposedly well prepared to use various inquiry processes with his high school physics students, but his teaching practice resulted in confusion. The physics students being taught were rather new to inquiry, the cooperating teacher having used more of a didactic approach with traditional lecture and "cookbook" labs prior to the student teacher's arrival. The student teacher gave his students a clear performance objective, provided the students with suitable materials, and essentially told them to "do science." The students leapt out of their seats and moved into the lab with joyful anticipation of "doing science." After about 15 minutes of lab activity it became painfully clear to both the student teacher and the university supervisor that the students were floundering. One student called out, "This is a waste of time!" Another vocalized, "We don't know what's going on." Yet another blurted, "We need some help over here." It turned out that the students had no idea how to "do science" at the specified level of performance.

Dengan demikian menjadi jelas bahwa pentingnya menerapkan levels of inquiry dalam pembelajaran secara sistematis agar mampu memfsilitasi siswa dalam mengembangkan kemampuan dan keterampilan sains siswa serta tidak menimbulkan kebingungan dalam diri mereka ketika mengikuti pembelajaran tersebut. Oleh karena itu, pengajaran yang berorientasi pada inkuiri tidak lagi dilihat sebagai gabungan dari proses-proses yang tidak berhubungan, namun digunakan secara sistematis sebagai serangkaian pendekatan hirearkis dengan keterampilan-keterampilan proses yang berafiliasi (Wenning, 2011).

\section{a. Tahapan Levels of Inquiry}

Dalam praktek pembelajaran, levels of inquiry terdiri atas beberapa tahapan yang bersifat hirearkis dan sistematis. Tahapan-tahapan tersebut dimulai dari discovery learning, interactive demonstration, inquiry lesson, inquiry lab hingga hypothetical inquiry.Perbedaan masing-masing tahapan inkuiri terletak dalam dua hal yaitu pengalaman intelektual dan lokus kontrol seperti pada Tabel 1.

Tabel 1. Hirearki Levels of Inquiry(Wenning, 2005)

\begin{tabular}{|l|c|c|c|c|}
\hline $\begin{array}{c}\text { Discovery } \\
\text { learning }\end{array}$ & $\begin{array}{c}\text { Interactive } \\
\text { demonstration }\end{array}$ & Inquiry lesson & Inquiry lab & $\begin{array}{c}\text { Hypothetical } \\
\text { inquiry }\end{array}$ \\
\hline Rendah & $\leftarrow$ Pengalaman Intelektual $\rightarrow$ & Tinggi \\
\hline Guru & $\leftarrow$ Lokus Kontrol $\rightarrow$ & Siswa \\
\hline
\end{tabular}


Berdasarkan Tabel 1 dapat disimpulkan ketika levels of inquiry bergerak dari kiri ke kanan, pengalaman intelektual yang dibutuhkan dan terlibat akan semakin tinggi serta lokus kontrolnya berpindah dari guru ke siswa. Hal ini berarti bahwa semakin tinggi levels of inquiry yang digunakan dalam pembelajaran maka akan membutuhkan dan melibatkan pengalaman intelektual yang tinggi pula, sedangkan porsi keterlibatan dan kontrol pembelajaran berada pada siswa.

Adapun hirearki pendekatan pengajaran levels of inquiry secara rinci dapat diuraikan sebagai berikut:

\section{Discovery learning}

Merupakan tahapan dasar dari levels of inquiry yang dicirikan dengan adanya proses penemuan “eureka! I found it” dalam kegiatan pembelajaran(Wenning, 2005). Tahapan ini dapat membantu siswa untuk mengembangkan konsep-konsep berdasarkan pada pengalamanpengalaman yang diarahkan guru.Wenning(2011) mengemukakan langkah-langkah yang dapat dilakukan dalam mengembangkan konsep siswa tersebut yaitu:

a). Siswa dihadapkan pada satu atau lebih fenomena sains yang menarik terkait dengan materi yang akan dipelajari.

b). Siswa diminta untuk mendeskripsikan pengamatan mereka terhadap fenomena yang disajikan tersebut.

c). Siswa didorong untuk mengidentifikasi situasi lain yang hampir sama.

d). Siswa diminta untuk mengubah variabel dan mengamati efeknya terhadap fenomena yang disajikan melalui kerja sama dalam kelompok kecil.

e). Siswa diminta untuk menentukan hubungan, menyimpulkan dan mengembangkan pengetahuannya.

f). Guru menentukan konsep penting terkait dengan penemuan siswa tersebut.

Pada tahapan discovery learning ini terlihat bahwa peran guru masih dominan dalam membimbing siswa untuk menemukan konsep dan membangun pengetahuan berdasarkan pengalaman yang dimiliki siswa.Bentuk bimbingan guru tersebut melalui rangkaian pertanyaan yang tepat terkait fenomena yang disajikan tersebut.

\section{Interactive demonstration}

Pada tahap ini guru bertugas untuk melakukan suatu demonstrasi, mengembangkan dan mengajukan pertanyaan prediksi dan eksplanasi, memancing respon dan penjelasan lebih jauh oleh siswa, serta membantu siswa dalam memperoleh kesimpulan berdasarkan bukti dari 
demonstrasi yang mereka amati. Ketika guru melakukan demostrasi tersebut, secara tidak langsung akan membantu siswa dalam memahami dan mempelajari proses-proses inkuiri.

\section{Inquiry lesson}

Penekanan pada tahap ini mengarah kepada proses melakuka eksperimen ilmiah melalui strategi bertanya yang tepat oleh guru. Fungsi guru adalah membantu dan membimbing siswa untuk merumuskan pendekatan eksperimen, mengidentifikasi dan mengontrol variabel. Langkahlangkah yang dapat dilakukan pada tahap inquiry lesson yaitu: guru mengidentifikasi fenomena yang akan dipelajari dan menentukan tujuan penyelidikan, siswa diminta untuk menentukan variabel-variabel terkait dengan penyelidikan tersebut (variabel bebas dan terikat), siswa diminta untuk menyusun dan melakukan serangkaian percobaan terkontrol untuk menentukan pengaruh variabel bebas terhadap variabel terikat secara kualitatif, serta melalui bimbingan guru siswa diminta untuk menentukan hubungan atau prinsip yang menggambarkan hubungan antar variabel tersebut secara sederhana(Wenning, 2010). Berdasarkan langkah-langkah pada tahapan inquiry lesson ini, maka dapat dipahami bahwa pergerakan lokus kontrol lebih mengarah kepada siswa serta mulai melibatkan dan menggunakan pengalaman intelektual yang lebih tinggi.

\section{Inquiry lab}

Pada tahap ini siswa diberi kesempatan secara mandiri untuk mengembangkan dan melaksanakan rencana eksperimen dan mengumpulkan data yang tepat, sehingga siswa mampu menemukan hubungan yang pasti antar variabel. Berdasarkan lokus kontrol serta pengalaman intelektual yang terlibat, inquiry lab dapat dibagi menjadi tiga tipe yaitu guided inquiry, bounded inquiry dan free inquiry(Wenning, 2005). Keterlibatan guru dalam tiap tipe inquiry lab tersebut berbeda sebagaimana yang diuraikan pada tabel 2 berikut ini.

Tabel 2. Karakteristik tiap jenis inquiry lab

\begin{tabular}{|c|c|c|}
\hline Jenis Inquiry Lab & Sumber Masalah/Pertanyaan & Prosedur \\
\hline Guided Inquiry & $\begin{array}{l}\text { Guru mengidentifikasi } \\
\text { masalah untuk diteliti }\end{array}$ & $\begin{array}{l}\text { Dituntun oleh } \begin{array}{r}\text { banyak } \\
\text { pertanyaan }\end{array} \\
\text { diidentifikasi oleh guru; } \\
\text { orientasi } \\
\text { sebelum-lab }\end{array}$ \\
\hline Bounded Inquiry & $\begin{array}{l}\text { Guru mengidentifikasi } \\
\text { masalah untuk diteliti }\end{array}$ & 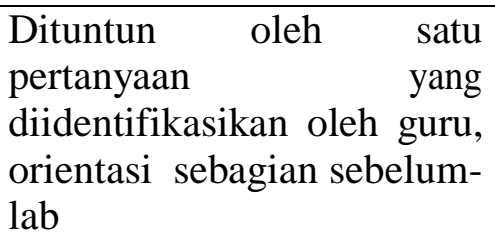 \\
\hline Free Inquiry & $\begin{array}{l}\text { Siswa mengidentifikasi } \\
\text { masalah untuk diteliti }\end{array}$ & $\begin{array}{llr}\begin{array}{l}\text { Dituntun } \\
\text { pertanyaan }\end{array} & \text { oleh } & \text { satu } \\
\text { yang }\end{array}$ \\
\hline
\end{tabular}




\begin{tabular}{|l|l|l|}
\hline & $\begin{array}{l}\text { diidentifikasi oleh siswa; } \\
\text { tidak ada orientasi sebelum- } \\
\text { lab }\end{array}$ \\
\hline
\end{tabular}

\section{Hypothetical inquiry}

Merupakan tahap paling tinggi dari levels of inquiry yang diterapkan pada siswa-siswa sekolah menengah ke atas. Pada tahapan ini siswa diminta untuk merumuskan dan menguji hipotesis secara mandiri.Hypothetical inquiry terdiri atas dua tipe yaitu pure hypothetical inquiry dan appliedhypothetical inquiry. Salah satu perbedaan antara kedua tipe ini terletak pada tujuannya, dimana pure hypothetical inquiry hanya bertujuan untuk memperluas dan memperkaya pemahaman tentang hukum-hukum alam, sedangkan applied hypothetical inquiry bertujuan agar siswa mampu menemukan aplikasi pengetahuan sebelumnya terhadap masalah-masalah baru dalam kehidupan nyata.

\section{b. Keterampilan Proses Sains}

Keterampilan proses merupakan keterampilan yang melibatkan keterampilan-keterampilan kognitif atau intelektual, manual, dan sosial (Rustaman, 2007). Dalam pengertian lain disebutkan bahwa keterampilan-keterampilan proses sains adalah keterampilan intelektual yang dapat dipindahkan, yang tepat untuk semua usaha ilmiah(Chabalengula \& dkk, 2012). Sedangkan Trianto(2014)mendefenisikan keterampilan proses sains sebagai keseluruhan keterampilan ilmiah yang terarah (baik kognitif maupun psikomotor) yang dapat digunakan dalam menemukan suatu konsep, prinsip, atau teori untuk mengembangkan konsep yang telah ada sebelumnya maupun untuk melakukan penyangkalan terhadap suatu penemuan/flasifikasi. Dengan demikian dapat disimpulkan bahwa keterampilan proses sains merupakan keterampilan yang digunakan dalam rangka kegiatan ilmiah untuk membangun pengetahuan yang melibatkan potensi kognitif, manual atau psikomotor dan sosial dalam diri pembelajar. Keterampilan kognitif atau intelektual terlibat karena dengan melakukan keterampilan proses siswa menggunakan pikirannya. Keterampilan manual jelas terlibat dalam keterampilan proses karena mungkin mereka melibatkan penggunaan alat dan bahan, pengukuran, penyusunan atau perakitan alat. Dengan keterampilan sosial dimaksudkan bahwa mereka berinteraksi dengan keterampilan proses, misalnya mendiskusikan hasil pengamatan (Rustaman, 2007). Oleh karena itu, keterampilan proses sains dapat mengembangkan potensi peserta didik pada ranah kognitif, manual atau psikomotor maupun sosial apabila dilatihkan dalam pembelajaran secara benar, misalnya dengan menerapkan Level of Inquiry dalam pembelajaran di sekolah. 
Keterampilan Proses Sains dalam pembelajaran IPA di sekolah dapat dibagi menjadi beberapa jenis.Funk (dalam Trianto, 2014) menyatakan bahwa keterampilan proses sain terbagi ke dalam dua kategori yaitu keterampilan dasar dan terpadu.Sedangkan Chabalengula \& dkk(2012) mengemukakan bahwa:

Science process skills are in two categories which are basic and integrated skills. Basic process skills include observing, inferring, measuring, communicating, classifying, predicting, using time space relations and using numbers. Integrated process skills include controlling variables, defining operationally, formulating hypotheses, formulating models, interpreting data and experimenting).

Dengan demikian keterampilan proses sains dibagi menjadi dua kategori yaitu keterampilan dasar meliputi; mengamati, menyimpulkan, mengukur, mengkomunikasikan, mengklasifikasi, memprediksi, menggunakan hubungan-hubungan ruang waktu dan menggunakan bilangan serta keterampilan proses terpadu meliputi; mengontrol variabel, mendefinisikan secara operasional, merumuskan hipotesa, merumuskan model-model, menafsirkan data dan bereksperimen.

Adapun jenis-jenis keterampilan proses sains beserta karakteristiknya secara rinci dapat diuraikan sebagai berikut(Rustaman, 2007):

1) Melakukan pengamatan (observasi):Menggunakan indera penglihat, pembau, pendengar, pengecap, dan peraba pada waktu pengamatan merupakan kegiatan yang sangat dituntut dalam belajar IPA. Menggunakan fakta yang relevan dan memadai dari hasil pengamatan juga termasuk keterampilan proses mengamati.

2) Menafsirkan pengamatan (interpretasi):Mencatat setiap hasil pengamatan termasuk menafsirkan atau interpretasi.Menghubung-hubungkan hasil pengamatan menunjukkan bahwa siswa melakukan interpretasi. Begitu pula jikasiswa menemukan pola atau keteraturan dari satu seri pengamatan danmenyimpulkan.

3) Mengelompokkan (klasifikasi):Dalam proses pengelompokkan tercakup beberapakegiatan seperti mencari perbedaan, mengontraskan ciri-ciri, mencarikesamaan, membandingkan, dan mencari dasar penggolongan.

4) Meramalkan (prediksi):Keterampilan meramalkan atau prediksi mencakup keterampilanmengajukan perkiraan tentang sesuatu yang belum terjadi berdasarkan suatukecenderungan atau pola yang sudah ada.

5) Berkomunikasi:Membaca grafik, tabel atau diagram dari hasil percobaan termasukberkomunikasi dalam pembelajaran IPA. Menggambarkan data empirisdengan grafik, tabel, atau diagram juga termasuk berkomunikasi. Selain itutermasuk ke dalam berkomunikasi 
juga adalah menjelaskan hasil percobaan, menyusun dan menyampaikan laporan secara sistematis dan jelas.

6) Berhipotesis: Hipotesis menyatakan hubungan antara dua variabel, atau mengajukan perkiraan penyebab sesuatu terjadi. Dengan berhipotesis diungkapkan cara melakukan pemecahan masalah, karena dalam rumusan hipotesis biasanya terkandung cara untuk mengujinya..

7) Merencanakan percobaan atau penyelidikan: Beberapa kegiatan menggunakan pikiran termasuk ke dalam keterampilan proses merencanakan penyelidikan. Apabila dalam lembar kegaiatan siswa tidak dituliskan alat dan bahan secara khusus, tetapi tersirat dalam masalah yang dikemukakan, berarti siswa diminta merencanakan dengan cara menentukan alat dan bahan untuk penyelidikan tersebut. Menentukan variabel atau perubah yang terlibat dalam suatu percobaan juga termasuk kegiatan merancang penyelidikan. Selanjutnya menentukan variabel control dan variabel bebas, menentukan apa yang diamati, diukur atau ditulis, serta menentukan cara dan langkah kerja juga termasuk merencanakan penyelidikan. Sebagaimana dalam penyusunan rencana kegiatan penelitian perlu ditentukan cara mengolah data untuk dapat disimpulkan, maka dalam merencanakan penyelidikan pun terlibat kegiatan menentukan cara mengolah data sebagai bahan untuk menarik kesimpulan.

8) Menerapkan konsep atau prinsip: Apabila seorang siswa mampu menjelaskan peristiwa baru (misal banjir) dengan menggunakan konsep yang telah dimiliki (erosi dan pengangkutan air), berarti ia menerapkan prinsip yang telah dipelajarinya. Begitu pula apabila siswa menerapkan konsep yang telah dipelajari dalam situasi baru.

9) Mengajukan pertanyaan: Pertanyaan yang diajukan dapat meminta penjelasan, tentang apa, mengapa, bagaimana, atau menanyakan latar belakang hipotesis. Pertanyaan yang meminta penjelasan menunjukkan bahwa siswa ingin mengetahui dengan jelas tentang hal itu. Pertanyaan tentang mengapa dan bagaimana menunjukkan si penanya berpikir. Pertanyaan tentang latar belakang hipotesis menunjukkan si penanya sudah memiliki gagasan atau perkiraan untuk menguji atau memeriksanya. Dengan demikian jelaslah bahwa bertanya tidak sekedar bertanya tetapi melibatkan pikiran.

\section{c. Hubungan Levels of Inquiry dan Keterampilan Proses Sains}

Masing masing tahapan pada levels of inquiry melatihkan jenis keterampilan proses sainsyang berbeda ketika diterapkan dalam pembelajaran. Semakin tinggi tahapan levels of inquiry yang digunakan, kemampuan keterampilan proses sains yang terlibat juga semakin tinggi dan kompleks. 
Kesesuain antara levels of inquiry dan keterampilan proses sains yang dilatihkan dapat dilihat pada tabel 3

Tabel 3. Hubungan antara levels of inquiry dan Keterampilan proses sains

\begin{tabular}{|c|c|c|}
\hline No & Levels of Inquiry & Keterampilan Proses Sains \\
\hline 1 & Discovery learning & $\begin{array}{l}\text { Rudimentary skills: Mengamati, Mengumpulkan dan mencatat } \\
\text { data, Menarik kesimpulan, Berkomunikasi, } \\
\text { Mengklasifikasikan hasil-hasil, Mengukur secara metris, } \\
\text { Memperkirakan, Membuat keputusan, Menjelaskan, } \\
\text { Memprediksikan }\end{array}$ \\
\hline 2 & $\begin{array}{l}\text { Interactive } \\
\text { demonstration }\end{array}$ & $\begin{array}{l}\text { Basic skills: Mengidentifikasikan variabel-variabel, Membuat } \\
\text { tabel data, Membuat grafik, Menggambarkan hubungan } \\
\text { antar variabel, Memperoleh dan memproses data, } \\
\text { Menganalisa investigasi, Menentukan variabel-variabel } \\
\text { secara operasional, Merancang investigasi, } \\
\text { Bereksperimentasi, Berhipotesa, Membuat keputusan, } \\
\text { Mengembangkan model, Mengontrol variabel }\end{array}$ \\
\hline 3 & Inquiry lesson & $\begin{array}{l}\text { Intermediet skills: mengukur, merekam dan mengumpulkan } \\
\text { data, membuat tabel data hasil pengamatan, merancang dan } \\
\text { melakukan penyelidikan ilmiah, menggunakan tekonologi } \\
\text { dan matematika selama investigasi, menggambarkan } \\
\text { hubungan. }\end{array}$ \\
\hline 4 & Inquiry lab & $\begin{array}{l}\text { Integrated skills: Mengidentifikasikan masalah-masalah untuk } \\
\text { diselidiki, Merancang dan melakukan investigasi ilmiah, } \\
\text { Menggunakan teknologi dan matematika selama investigasi, } \\
\text { Menghasilkan prinsip-prinsip melalui proses induksi, } \\
\text { Berkomunikasi dan mempertahankan argumen ilmiah }\end{array}$ \\
\hline 5 & $\begin{array}{l}\text { Real world } \\
\text { application }\end{array}$ & $\begin{array}{l}\text { Culminating skills: mengumpulkan, menilai, menafsirkan data } \\
\text { dari berbagai sumber, membangun argumen logis } \\
\text { berdasarkan bukti ilmiah, membuat dan mempertahankan } \\
\text { keputusan berdasarkan bukti, menjelaskan nilai-nilai terkait } \\
\text { dengan alam, melatih keterampilaninterpersonal. }\end{array}$ \\
\hline
\end{tabular}




\begin{tabular}{|l|l|l|}
\hline 6 & Hypothetical inquiry & $\begin{array}{l}\text { Advanced skills: Memecahkan masalah-masalah dunia nyata } \\
\text { yang komplek, Mensintesa penjelasan-penjelasan hipotetis } \\
\text { yang komplek, Membuat hukum-hukum empiris } \\
\text { berdasarkan pada bukti dan logika, Menganalisa dan } \\
\text { mengevaluasi argument-argumen ilmiah, Membuat bukti- } \\
\text { bukti logic, Menghasilkan prediksi-prediksi melalui proses } \\
\text { deduksi Inquiry hipotetis. }\end{array}$ \\
\hline
\end{tabular}

Berdasarkan tabel 3.terlihat bahwa dalam setiap tahapan levels of inquiry melatihkan berbagai jenis keterampilan proses sains sesuai dengan jenjang atau levelnya, mulai dari rudimentary skills hingga advanced skills. Berdasarkan tabel3.terlihat bahwa dalam setiap tahapan levels of inquiry melatihkan berbagai jenis keterampilan proses sains sesuai dengan jenjang atau levelnya, mulai dari rudimentary skills hingga advanced skills. Dengan demikian, secara teoritis terdapat hubungan antara levels of inquiry dengan keterampilan proses sains terutama dalam pembelajaran IPA baik pada jenjang dasar menengah maupun jenjang pendidikan tinggi.

Selanjutnya, hubungan levels of inquiry dan keterampilan proses sains secara empiris juga sudah dibuktikan melalui penelitian oleh beberapa peneliti. Hasil-hasil penelitian tersebut menunjukkan bahwa levels of inquiry (LoI) dapat melatihkan, mengembangkan serta meningkatkan keterampilan proses sains siswa (Hartini, R.I.P., 2017; Fatimah, F., Susilo, H \& Diantoro, M., 2016; Ramdan, S \& Hamidah, I., 2015).

Hasil penelitian lain menyatakan bahwa profil perkembangan kemampuan bereksperimen yang di dalamnya memuat berbagai keterampilan proses siswa pada aspek mendesain eksperimen memiliki perkembangan yang paling rendah, meskipun dalam implementasi ini guru memiliki dominasi yang lebih besar. Oleh karenanya perlu dikembangkan cara-cara yang lebih fokus terhadap melatihkan kemampuan mendesain eksperimen terutama pada tahapan interactive demonstration dan inquiry lesson dengan lebih menekankan dominasi peran siswa di dalam pembelajaran (Danika, I., dkk, 2018).

Penelitian lain yang dilakukan oleh Nurinsani, E.A., dkk (2018) dengan subjek penelitian yaitu siswa kelas VIII SMPN 12 Bandung yang terdiri dari 24 orang. Hasil penelitian menunjukkan bahwa pada aspek meramalkan gambaran eksperimen meningkat lebih baik di banding aspek lainnya, meskipun dalam prosesnya penggunaan LoI ini dominasi guru masih lebih kental. Peran Discovery Learning dan Interactive Demonstration telah memberikan cara-cara yang baik meskipun dominasi guru 
cukup kental, namun dalam langkah Interactive Demonstration dan Inquiry Lesson perlu difikirkan langkah yang lebih fokus dalam melatihkan kemampuan berhipotesis dan mendesain eksperimen.

\section{Kesimpulan}

Penerapan levels of inquiry secara sistematis dan hirearki dalam pembelajaran IPA akan dapat memfasilitasi siswa untuk meningkatkan kemampuan keterampilan proses sains mereka karena setiap tahapan levels of inquiry mengandung satu jenis keterampilan proses sains yang berbeda. Semakin tinggi tahapan levels of inquiry maka keterampilan proses sains yang terlibat dan dilatihkan juga semakin kompleks dan tinggi pula, mulai dari rudimentary skills, basic skills, intermediate skills, integrated skills, culminating skills hingga advancedskills.

\section{Daftar Pustaka}

Chabalengula, V. W., \& dkk. (2012). How Pre-service Teachers' Understand and Perform Science Process Skills. Eurasia Journal of Mathematics, Science \& Technology Education, 8(3), 167-176.

Danika, I., dkk. (2018). Profil Perkembangan Kemampuan Bereksperimen Siswa SMP pada Pembelajaran Levels Of Inquiry (Loi) Materi Energi. Jurnal Wahana Pendidikan Fisika, 3(1), $108-113$.

Fatimah, F., Susilo, H \& Diantoro, M. (2016). Keterampilan Proses Sains Siswa Kelas VII dengan Pembelajaran Model Levels Of Inquiry. Jurnal Pendidikan: Teori, Penelitian dan Pengembangan, 1(9), 1706-1712.

Hartini, R.I.P. (2017). Penggunaan Levels Of Inquiry Dalam Meningkatkan Keterampilan Proses Sains Siswa. Jurnal Ilmu Pendidikan Fisika, 2(1), 19-24.

Nurinsani, E.A., dkk. (2018). Penerapan Levels Of Inquiry (LoI) untuk Mengidentifikasi Perkembangan Kemampuan Bereksperimen pada Materi Tekanan di SMP. Jurnal Wahana Pendidikan Fisika, 3(1), 114-119.

Ramdan, S \& Hamidah, I. (2015). Peningkatan Keterampilan Proses Sains Siswa Smp Melalui Penerapan Levels Of Inquiry Dalam Pembelajaran Ipa Terpadu. Jurnal Edusains, 7(2), 105113.

Rustaman, N. (2005). Strategi Belajar Mengajar Biologi. Malang: Universitas Negeri Malang. Rustaman, N. (2007). Keterampilan Proses Sains. Bandung: Universitas Pendidikan Indonesia. Trianto. (2014). Model pembelajaran Terpadu: Konsep, Strategi, dan Implementasinya dalam KTSP. Jakarta: PT. Bumi Aksara. 
Wenning, Carl. J. (2005). Levels of inquiry: Hierarchies of pedagogical practices and inquiry processes. Journal Physics Teacher Education Online, 2(3), 3-12.

Wenning, Carl. J. (2010). Levels of inquiry: Using inquiry spectrum learning sequences to teach science. Journal Physics Teacher Education Online, 5(3), 11-20.

Wenning, Carl. J. (2011). Levels of Inquiry Model of Science Teaching: Learning sequence tolesson plans. Journal Physics Teacher Education Online, 6(2), 17-20. 